\title{
The advantages of micro-credit lending programs and the human capabilities approach for women's poverty reduction and increased human rights in Bangladesh
}

\author{
Rouf, Kazi Abdur $\bowtie$ \\ Ontario Institute for Studies in Education, University of Toronto, Canada (rouf56@hotmail.com)
}

Received: 26 December 2011

Available Online: 10 February 2012

Revised: 5 February $2012 \quad$ Accepted: 8 February 2012 DOI: $10.5861 /$ ijrsm.2012.v1i2.65

\section{Abstract}

Fifty percent of people all over the world are suffering from a lack basic needs. Even poor women are denied their equality of human rights. Equality of rights for these women would mean access to food, clothing, shelter, and credit as well as liberation from exploitative forms of income generation such as domestic work, child labor and trafficking. Women in Bangladesh suffer from inequality of rights on quite an unimaginable level and their socio-economic development has been largely impeded. Thus, these poor women depend on others to survive. Human capability services like education and skills development services are not generated nor tailored to them particularly at the village level which affects the basic human rights of these women. Without educational, health, economic and social services at the village grass-roots level, poor people suffer most in Bangladesh. Although the Constitution of Bangladesh appears to strongly approve gender equality and positive action that guarantees women's full participation in social, economic and political life, it is clear that full support is absent. Ironically, the disadvantaged poor people specifically are struggling to fulfill their basic human needs and are aware of their basic human rights. Although some steps have been made to reduce gender inequality, some laws still lag behind and many discriminatory practices are found in the customary laws, which still remain in force. A solution that has offered to assist poor women in Bangladesh through micro-credit organizations (MFIs) like Grameen Bank credit, that create opportunities for these women to help educate themselves and overcome poverty in Bangladesh. However, human rights education at the grass roots level is very nominal. Hence focus on human rights education extension programs are urgently required to establish basic human rights.

Keywords: Grameen Bank; human rights; women human rights; micro-credit; feminization of poverty; participatory development; women empowerment

Acronyms: Bangladesh Rural Advancement Committee (BRAC), Apllikarma Shayak Foundation (PKSF), Structural Adjustment Policy (SAP) 


\section{The advantages of micro-credit lending programs and the human capabilities approach for women's poverty reduction and increased human rights in Bangladesh}

\section{Introduction}

The "feminization of poverty" has been a growing concern in low-income countries such as Bangladesh. In this essay, the feminization of poverty refers to the burden placed on poor women in Bangladesh to feed, clothe and nurture their families and themselves. Poor women are denied access to credit. The development of women has been largely impeded, and women in Bangladesh suffer from inequality of rights on quite an unimaginable scale. Equality of rights for these women would mean access to food, clothing, shelter, and credit as well as liberation from exploitative forms of income generation such as domestic work, child labor and trafficking. There is a major lack of resources to support women in their struggle to work, take care of their families and survive. This struggle is often the result of macro- and micro-economic gender divisions, which reflect current political practices and the norms, customs and culture of the patriarchal society. Therefore, the $50 \%$ people suffer from a lack of basic needs. Human capability services like education and skills development services are not generated and tailored at the village level which affects basic human rights. Without educational, health, economic and social services at the village grass-roots level, poor people suffer most. Rich people exploit the poor and hinder their human rights and other legal rights. The effects of colonialization and globalization have also contributed to the poor conditions in Bangladesh, first with British rule and then the Pakistan regime between 1947 and 1971 .

Although there are several international organizations and programs designed to help combat these injustices, often their techniques are not applied uniformly, and thus civil society has less power to lobby for the necessary changes in the legal system (Quadir, 2003). A promising new strategy, first introduced by Professor Mohamed Yunus, brought to Bangladesh the concept of micro-financing. Micro-credit has proved successful thus far in providing poor women with the ability to generate income while developing human capabilities. The positive effects associated with such activities have helped reduce poverty in some rural areas, as well as increase women's equality and human rights. However, micro-credit and human capabilities development can only thrive in conjunction with successful implementation, government support and services, and international involvement. Thus, this essay will argue that the "feminization of poverty" in Bangladesh can be reduced through the development and successful implementation of micro-credit lending programs that increase human capabilities and provide a means of achieving gender equality and human rights for rural poor women.

\subsection{Problems}

Poor women in Bangladesh do not have basic human rights. Basic human rights in this essay will include food, clothing, shelter, health and education. With no food, clothing and shelter, women are forced to beg, or borrow money. Borrowing money from money lenders leads to great debt, which in turn leads to landlessness and vulnerability in society.

\section{Context}

Currently, Bangladesh has 164.4 million people within a 147, 570 square kilometer range. The density of the population is 763 people per square kilometer and the per capita income is $\$ 370$. In Bangladesh 51\% poor people live under the poverty line. This rate is highest in South East Asia. The poverty rate of rural areas in Bangladesh is higher than the national average of 51\%. The Bangladesh Human Development Report 2000 reported that during the period between 1992 and 1996 the rural poverty line declined by about 1\% per year and had dropped from $53 \%$ to $51 \%$. Yet, a population growth rate of $2.3 \%$ per year was not considered in this estimation; thus, despite this decline, rural poverty is still highest in South East Asia. Because poor Bangladeshi women are not 
provided state resources, their human rights are seriously hampered, as well as other social civil rights like freedom of choice, freedom of speech, and opportunities in society.

Approximately $86.6 \%$ of the population is Muslim. Therefore, Bangladeshi society is a highly patriarchal Muslim dominated society where all household family decisions are made by men. Men control women's labor, women's choice of marriage, access to resources, and legal, social, health, economic and political institutions are mediated by men. Rural women have no autonomy in their life from childhood well into adulthood and old age. Public and private institutions underpin gender subordination and dependence. Women are treated as an unpaid reproductive agent for the family and are involved in unpaid family subsistence agricultural work. Women are discouraged by their male "guardians" not to participate in public or private paid employment outside of the home. Although, public and private sector job opportunities are very limited. Thus, Bangladesh has a high unemployment rate of approximately $52.5 \%$. However, it is important to stress that employment opportunities for women in particular, are required so that unmarried, divorced, and widowed women can provide for themselves and their families. Furthermore, there is no value associated with domestic work such as, housework and even social reproduction. Less wage work results in women's low economic status. Poor women do not have access to credit from formal financial services to do business. Some of them become street beggars after losing all that they own through the mortgaging of their assets. Consequently, these women are left with no rights and no power in the society.

In addition, women who lack education cannot develop the proper skills that will help them find employment. In fact, the adult female literacy rate is 43\% (Bangladesh Human Rights Report, 2000). However, the rural female literacy rate is far lower than the national average. If women are unable to find jobs, they cannot provide for themselves and their families. Thus, educated women are more aware of their poor conditions and are better equipped to lobby and fight for their rights. Only $30 \%$ of the total population has access to basic health services, and $76 \%$ of all households are deficient in calorie intake (CIDA, 2001). Without access to health care, poor women face malnutrition and death. This makes them very weak, perhaps even too weak to work and provide for themselves and their families. In addition, malnutrition leads to the spread of diseases, which can affect the entire country and not just marginalized sections of the population. Lack of fundamental resources, affords these women no power and therefore they are unable to exercise their human rights. Kabeer (2003) states that in order to establish gender equality and female empowerment as well as reduce female poverty, Bangladesh needs to close the gender gap in education, increase women's employment and wages, and increase women's participation in parliament.

\section{Causes}

Before 1947, Bangladesh was a part of India, and then between 1947 and 1971 it was under Pakistan. The effects of Pakistan rule in Bangladesh will be discussed later in more detail. The birth of new social classes (petty bourgeoisie) in Bangladesh before 1947 was the result of the destruction of the old social economy and superimposition of new social policies by the colonial rulers (Alam, 1995). British imperialism created a new class structure, which was absent in India. Although presently it appears that a democratically elected civilian authority governs Bangladesh, it is really governed by the petty bourgeoisies, who are now a ruling class comprised of an emerging middle class, the rich business class, and the military and bureaucratic forces.

In addition, there is a history of dependency on foreign capital that exists within the government of colonial powers (Novak, 1993). This government is unable to contribute to a sustainable economic development project for the poor. Therefore, the country is experiencing hegemonic crisis and political instability. Consequently, as Foucault would argue, the notions of power and knowledge related to "participatory development" are inherently anti-nature and anti-women in Bangladesh (Shiva, 1988). As such, although the ruling class in Bangladesh receives foreign aid, the funds are not used for the welfare of poor people. The ruling class would rather use the money for their own interests. This produces misery and inequality in the society (Alam, 1995). 
It is clear that British colonialization in Bangladesh has had a negative effect on macro- and micro-economics in terms of gender divisions in labor and within social contexts. These kinds of societal organizations have only supported ideas of subordination and encouraged the birth of many forms of inferiority. Class relations are an important contribution to this discussion because it is often the money lenders that poor women turn to for "support." Poor women in Bangladesh are being exploited by government macro-economic policies and money lenders (Mohajan), and therefore are not afforded the basic human rights discussed above. Thus, poor, uneducated women depend on others to survive.

To maintain the family, poor people sell their labor in advance for one, two or even five years. The need to provide food and clothing to children forces poor women to become domestic aids in the homes of rich people. Poor people are forced to move from small rural villages to urban areas for survival. These people live in shanty slums that are in miserably low and unhygienic conditions. A majority of them are suffering from lack of Healthcare. They ultimately end up without food, clothing, shelter, health, education, security, and no choice. They become victims of malnutrition and deadly, crippling diseases. Some brothels take advantage of the troubled times of poor people and begin to traffic and prostitute desperate women and children. The result is an increase of injustice, inequality, and exploitation, which has an even worse impact on their lives.

Another important factor to consider is the maintenance of the male dominated patriarchal society in Bangladesh. Although Bangladesh declared itself a secular state, Muslim religious values dominate the society. These Islamic values are linked with politics in Bangladesh and often, political representatives lobby for their own political interests. Thus, when fundamental Islamic religious leaders become powerful in politics, women's rights are affected. This is because Islam values Sharia law which encourages male dominated patriarchy. Parvin Paidar (2002) notes the patriarchal nature of Islam and its subsequent oppression of women in Iran as well. Therefore, in Bangladesh, gender inequality and development discourse needs to acknowledge the contradictory affects of religious customary and legal laws that are often at the expense of women's human rights.

In addition, as Beneria (2003) notes, with globalization and industrialization, trade became more commercialized, which made profit the motivating factor for work. Market forces in the formal and informal sectors of the economy are also important to the understanding of the feminization of poverty because, as previously discussed; women's work goes largely unnoticed in these sectors as does their unpaid labor and reproductive contributions. Dollar and Gatti (2003) and Seguino (2003) provide some interesting findings about the division of labour throughout their respective studies. These will be discussed later in further detail with a focus on macro- and micro-economic policies and their impact on gender-divisions.

The impact of globalization and commercialism can best be illustrated with a discussion of British Imperialism in Bengal and its post-colonial effects. The British East India Company first introduced British rule in Bengal in 1750. Its purpose was to build a trade market between India and England. Shortly afterward, this company introduced the idea of private ownership similar to the West, and land became an important commodity. A new upper class of "landlords" (Zamindars) emerged who were revenue collectors during the Moghal Emperors (Karim, 1976). In 1773, the British introduced the Permanent Land Settlement Act. This new system introduced and forced farmers into cash crop production and commercialized agriculture. British metropolises remained linked to India by establishing metropolis satellite structures (Frank, 1970). They diverted agriculture in order to supply raw materials to industries in England, which transformed Bengal into a market for finished products for England. As Boserup's (1970) literature would suggest changes in the production of agriculture effects women and the land, their roles, and the decline of women's equality from pre-colonial to colonial times. Thus, the conflict between gender and class relations becomes more apparent. Although Bangladeshi women contribute to the majority of agricultural production as well as within the informal sectors of the economy, they are still suffering from non-paid and undermined informal household and farming labor.

Another important contribution to the discussion on gender and class relations relates to the British educational policy that created a Hindu educated middle class in Bengal known as "gentlemen" (bhadralok). 
Micro-credit lending programs and the human capabilities approach in Bangladesh

According to Gramsci (1971) this class would fall under the category of "organic intellectuals". Organic intellectuals are involved in various bureaucratic and professional duties that are necessary to mediate British rule in India. Muslims in India refused to collaborate with the British and rejected learning English as Muslim religious leaders declared the English language the language of "kafirs" (infidels). Therefore, in Bengal, Muslims are behind in education when compared to Hindus. This Hindu-Muslim differentiation later resulted in separate religious sentiments, movements and nationalism to preserve Indian Muslim culture. Thus, in 1947, this division led to the Pakistani acquisition of Bangladesh (East Pakistan).

With new rule, Pakistan introduced development projects which favored West Pakistan's own interests. This generated class and regional inequalities between West and East Pakistan. Once Bengali petty bourgeois articulated nationalist discourse on the basis of economic and political exploitation, they started to identify political and economic discrimination in the Pakistan public. As a result, in 1971 East Pakistani people revolted, and East Pakistan became Bangladesh. The development programs in Bangladesh created a parasitic class, who misspent public funds and caused the entire country to become impoverished. Huge foreign aid poured into Bangladesh in the name of public projects, but these funds were mishandled by the corrupt ruling class. This exacerbated the already terrible conditions for poor people.

A third factor contributing to the feminization of poverty today is globalization. Free market capitalism, globalization, democracy and technology are not worthwhile in Bangladesh, and worsen poverty, especially for women. This is because, macro-policies and programs are bureaucratic in nature (top down), and do not consider globalization's exploitative processes on Third World nations.

The invasion of multinational corporations is similar to the process of colonization. Multinationals come into the country of their choice, and exploit the people, the government and the resources, in the name of business. Like colonization, this changes the role of women in society and affects their human rights. Although the multinational corporations create some jobs in Bangladesh, these corporations care only about profits, which results in uneven economic growth in the country. For instance, in order to increase profits, multinationals find cheap labor and resources. Small businesses fail as they cannot compete with multinational products. In addition, multinational corporations ruin the environment and therefore people have no lands for agriculture, which is needed for survival. As Professor Patricia Stamp urges, we should not pressure nature for human benefit (Stamp, 1989). Human rights are also affected by multinational corporations. People are left to live in poverty, with no options for fighting against multinational corporations. In particular, women have no right to complain about work or complain about poverty and injustice as they have no power. Unfortunately, the Bangladeshi government relies on the money of multinational corporations and so they do not want to be rid of them.

Globalization literature (also referred to as "modernization literature") ignores traditional values and Third World countries are often depicted as falling behind. Professor Patricia Stamp disagrees with such literature and argues that it is not a question of whether such Third World societies are "behind," but rather, modernization imposes Westernized views that are not tailored to consider the economic, political and social practices of traditional Third World societies. Edward W. Said (1978) has noted that "orientalism" (the erroneous Western tendency to view all Middle Eastern and Asian cultures as a kind of homogenous whole and to place them within a false framework that is opposed to our own) is man-made for the West. The relationship between the Occident (Britain and the U.S.) and the Orient (Middle East and East Asia) is a relationship of power, a domination of hegemony. The interaction between the ruling classes and the state is the end result of a historical process to keep the country undeveloped (Said, 1978). This is very true as we note the effects of Western capitalist goals with respect to modernization.

Diane Elson (2003) provides some insight into becoming gender-aware in macro-economic policies and government budgets. She notes the importance of unpaid reproductive labor and the dynamic between gender inequality and capitalist markets. Macro-economic policy developments need to be evaluated and adjusted to reorganize gender differences with respect to economic growth. 


\section{Attempted Solutions}

The Bangladeshi Constitution calls for equality of all citizens before the law and no discrimination against any citizens on grounds of religion, race, sex, or place of birth; right to protection of the law; protection of right to life and personal liberty; freedom of speech, profession or occupation; rights to property; and enforcement of fundamental rights through courts of law. Any laws and enactments inconsistent with fundamental rights are void. The constitution of Bangladesh guarantees equal rights for women and men. However, there is still a large gap between the law and its actual implementation.

Article 25 of the Bangladeshi Constitution is vital to this discussion because it addresses the fulfillment of basic needs. Everyone has the right to a standard of living, adequate for the health and well-being of himself and of his family, including food, clothing, housing, medical care and necessary social services. However, in the constitution a provision for the same is made in Article 15 that the fulfillment of these basic needs is not a matter of rights, but rather, a state responsibility, which was unfortunately not included in the fundamental rights chapter of the Constitution. The above points illustrate that the constitution provides for the fundamental rights of its citizens, but fundamental needs are not fully recognized as rights of citizens. In addition, Article 10 of the Constitution notes, "Steps shall be taken to ensure participation of women in all spheres of national life" (BMSP, 1997). Ironically, the bottom $50 \%$ of disadvantaged poor people specifically is struggling to fulfill their basic human needs.

Although the Constitution of Bangladesh appears to strongly approve gender equality and positive action that guarantees women's full participation in the social, economic and political life, it is clear that full support is absent. There is a separate ministry for women's affairs and although some steps have been made to reduce gender inequality, some laws still lag behind and many discriminatory practices are found in the customary laws, which still remain in force.

A solution that was offered to assist poor women in Bangladesh began with Professor M. Yunus. Professor Yunus is the founder of the Grameen Bank. This organization argues that welfare or handouts do not help poor people (Yunus, 2002). Instead, the poor remain unskilled and continue to live in poverty. Grameen Bank credit creates opportunities for poor women in Bangladesh to help poor women educate themselves and overcome poverty.

Grameen Bank, a locally initiated model, provides credit to rural poor women without collateral. They serve 4 million families and provided 4.5 billion US dollars to its borrowers across Bangladesh. The credit recovery rate is $99 \%$ (Grameen Bank, 2005). It has not only had tremendous success in generating income to the bottom $50 \%$ disadvantaged women, but it has also empowered them to make choices, have a voice, and gain opportunities and bargaining power. It views credit for self-employment as a fundamental human right, which is a powerful weapon that grants access to other resources. Grameen Bank has helped poor women break out of the cycle of poverty by increasing the income of its borrowers. Grameen clients are able to overcome the deprivation of basic human needs and fundamental human rights.

Following the Gramen Bank model, other micro-credit organizations (Bangladesh Rural Advancement Committee, Association for Social Advancement, PRISHIKA, PKSF) in Bangladesh are also now providing credit to poor village women for income generating activities. Various studies in Bangladesh show that credit programs have a positive impact on the reduction of poverty. Kofi Annan (2005), the former Secretary General of the United Nations, said on January 15, 2005 that micro finance has proved its value in many countries as a weapon against poverty and hunger. It really improves peoples' lives, especially the lives of those who need it most (Annan, 2005). Therefore, it is very important for poor women to have an economic income base that can open the door to other social and political rights for women, equality, freedoms, as well as struggle against the violations of their human rights and social injustice.

International organizations also play a vital role in helping to reduce the feminization of poverty. One such 
Micro-credit lending programs and the human capabilities approach in Bangladesh

organization is the United Nations (UN). The United Nations has helped the world become more aware of this problem. A new strategy has been proposed by the UN that will include trying to implement development programs through the government. For instance, the Millennium Development Goals (MDGs) were agreed upon at the United Nations Millennium Summit in 2000 and include: (1) to half world poverty by 2015; (2) to achieve universal primary education and (3) to promote gender equality in order to help empower women. However, as previously discussed, some corrupt government bodies divert funds for their own preferences. Furthermore, rural poor people are not considered a priority in the government fiscal budget agenda. Poor people are suffering from the disadvantages of national budget resources. However, Women's equal access to financial resources is a human rights issue.

Other international organizations include, The World Bank, International Monetary Fund (IMF) and the World Trade Organization (WTO). These organizations took Third World countries and tried to push structural adjustment policies (SAPs) without tailoring the SAPs to each country. SAPs were intended to help the economic disturbances in Third World countries like Bangladesh. However, foreign debt adjustment did not consider gendered responsibilities in and outside the home. The World Bank promotes economic progress in developing countries. They try to raise productivity to help people live better lives. Their priorities are at the macro-level, but have less impact at the micro-level. IMF monitors international finance, encourages financial cooperation between countries, lobbies for state exchange rates and assists governments with debt. However, IMF does not specifically address women's issues. It does not focus on poverty reduction and its main concern is economic growth. Equal economic growth is also not addressed. IMF does not provide hands-on assistance. Their SAPs are designed only to correct maladjustments in their balance of payments. The WTO was formed in 1995 and its basic principle is that all 125 member countries must abide by WTO rules. Rules include barriers on tariffs, intellectual property rights, and investment and trade relations. However, the WTO does not address worker's rights and poverty..

A proposal offered by the World Bank and the IMF was the greater funding and implementation of non-governmental organizations (NGOs) through apex funding. The involvement of apex funding was required in order to help monitor the activities of NGO's. Otherwise, there would be an overlap of resources in some areas, leaving other areas with nothing. The autonomous apex funding body in Bangladesh is called the Pally-Karmar-Foundation (PKSF). They take funding and distribute it to NGO's and coordinate and monitor NGO activities. The advantages of this model include, less government control, and funds go directly to NGOs. NGOs provide services directly to the people. Some NGOs are working for mass education, some are involved in primary health care services, some provide agricultural support services and some promote women's human rights. The majority of NGOs are now involved in micro-credit programs, which target poor rural women and promote income-generating activities. Through diversified NGO activities, village people are connected to various development programs. The Ain-O-Salish Kendra undertakes a variety of programs to improve people's awareness of legal and human rights. Mohila Samity (Women Association) runs various programs to help women achieve self-reliance. In particular, in Bangladesh, many NGO's work with women, this is a massive thrust toward women's equality and progress.

Two international organizations born in the West include the Canadian International Development Agency (CIDA) and the US Agency for International Development (USAID). CIDA supports sustainable development in developing countries. They hope to reduce poverty and make the lives of poor people more secure and equitable. CIDA also supports democratic development. Its program is based on the Millennium Development Goals (MDGs) developed by the United Nations. CIDA has 4 main priorities: 1. social development; 2. economic well-being; 3. environmental sustainability; and 4. governance. There is a greater emphasis on human rights issues, democracy and good governance to help reduce corruption by governments. Also, equitability between men and women is promoted and supported by CIDA. The CIDA approach is more appropriate for Bangladesh in order to increase gender equality, human rights and human capital development of poor women.

On the other hand, US foreign assistance has always had the twofold purpose of furthering America's 
foreign policy interests in expanding democracy and free markets while improving the lives of the citizens of the developing world. USAID appears to be very general and vague about their policies and work in developing countries. Their policy objectives focus on economic growth, trade and democracy, and conflict prevention. USAID is unclear about how it helps economic growth and eradicates poverty. They do not focus on women's human rights and equity. They focus on terrorism and weapons of mass destruction. Oddly, education is not a priority even though education is a basic requirement for human capital and for human rights. Thus, it is clear that CIDA support is more oriented to promoting human rights, reducing poverty, and macro- and micro-level social and economic development in developing countries. Conversely, USAID is more concerned with US interests like foreign policy, commercialism, trade, globalization and an emphasis on capitalist democracy within a US context.

The purpose of these organizations is to stabilize currency and ensure free trade. Yet, none of these organizations have yet emerged as key contributors in Bangladesh civil society (Quadir, 2003). The big three (World Bank, IMF and WTO) reflect the interests of the capitalist powers. In fact, there is public opposition against some World Bank policies. Not only do people feel that these institutions develop devastating SAPs which negatively affect the poor, but feminist scholars also believe that the World Bank ignores women's issues and maintains gender inequality. Currently, a piecemeal system exists between NGOs and civil society. They need more coordination so that a complete package is implemented at the grass-roots level. Therefore, Bangladesh needs a national NGO who solely deals with the village people to counsel, advocate and lobby for women's human rights, stand against dehumanization, and work for victims assisting them in legal issues and prosecution.

\section{Directions for the Future}

As public and private sector formal jobs are limited, government resources and support for the villages is bleak. Rural poverty is increasing at an alarming rate in comparison to its population growth. Therefore an independent income program, a universal education program and strong law enforcement can create the potential to enhance women's income, awareness, capabilities and status at home and in the community. Income and gender specific programs can benefit women because "micro-finance is a vital means for income generation, social inclusion, and empowerment" (Chowdhuray, 2005). The Grameen Bank program has proved the success of micro-credit. Distressed women are provided with education, skills, training, credit, and other support services for income generating purposes. This leads to economic progress, a boost in family and social status, independent decision-making, and the development of self-confidence that empowers. Women's empowerment may lead to government participation at the local level. This participation is important for achieving the goals associated with women's human rights.

Increased human capabilities have a positive impact on both gender equality and economic growth (Nassubum, 1988). Studies conducted by Dollar and Gatti (2003) and Seguino (2003) illustrate a positive relationship between gender equality, efficiency and economic growth. In addition, Seguino (2003) suggests that there is a trade-off between gender equality and economic growth. Therefore, investment in human capital will improve efficiency and will inevitably have a positive impact on economic growth.

Micro-level programs, such as micro-credit, will help eradicate social discrepancy, gender inequalities, and other social catastrophic activities, which affect the poor women in rural Bangladesh. However, programs such as Grameen Bank (GB), along with other micro-finance institutions, only serve 14 million rural people composed of GB 4.00 million, PKSF 5.2 million, Bangladesh Rural Advancement Committee (BRAC) 3.9 million, and Others 1.00 million and therefore, a large population still has no access to financial services. Therefore commercial banks and other financial institutions need to be government regulated to simplify collateral conditions and reduce banking bureaucracy.

Raising awareness through legal education and reform can challenge existing public policies and laws to 
empower victimized women. As Paulo Freire (1981) would suggest, ignorance leads to unequal power and exploitation. Thus, the government should promote and execute universal compulsory primary education with a special emphasis on female education. This will help poor women develop human capabilities and human dignity.

Besides education, the government needs to initiate greater support at the social, economic, and political micro-level. For instance, rural poor women are involved in informal agricultural and non-agricultural work. Their work is not included in the country's economic production and social reproduction goes unnoticed. Because of the domestic (household) nature of this work, it is stereotyped as "women's work" which leaves poor women out of the fiscal budget. Therefore, the government should develop labor intensive special income generating projects in the rural areas for these poor women so that their activities will be included within the development programs.

In addition, deficient macro-policies can easily limit the development of poor women. A micro-economic policy framework for maintaining poor women's development may be more conducive to sustainable development and poverty reduction. Social mobilization is a pre-condition for improving the access, equity and quality of public services available at the local level. The government of Bangladesh can implement a massive social mobilization program to encourage rural communities to solve their own common concerns and share any available local resources among themselves.

A special judiciary bench may be established at the district level to deal with violence against rural poor women and to enforce laws regarding trafficking, dowry, rape, forced prostitution, and acid throwing. Courts at the local level need to criminalize and penalize the traffickers, syndicates and operators. At the same time, the victims of these crimes need to be empowered in order to help them rebuild their lives. This can be accomplished through rehabilitation in health and the provision of other social services. Men should be made to take responsibility for their sexual behavior and so the courts need to strictly enforce the existing laws with the help of honest law-enforcing personnel.

Margaret Shuler's "Strategy Matrix" provides techniques to work with the structural components of the law, so that we may find a strategy to assist women in Bangladesh who face violations of human rights. Strategies need to improve women's access to the legal system and services. The gender network committee at the upzilla (sub-district level) can be set up to monitor legal actions and enforcement of legal laws for establishing women's human rights.

At the same time the international community should also come forward and create pressure for governments to take serious action and to eliminate poor women's human rights violations. The Millennium Development Goals are an example of such action. However, without the development of women, Bangladesh will not be able to successfully accomplish their MDGs. Therefore, if a country wants to address the feminization of poverty, it also needs a clear definition of who constitutes poor women (bottom 50\%) so that any projects or programs designed to assist poor women can be exclusively created for the bottom $50 \%$ of women.

Although this essay covers all three MDGs as well as their targets and indicators, I want to stress the urgent need to include another target under the first MDG. That is to establish poor women's human rights by promoting income generating programs and self-employment through the provision of collateral free micro-credit. The urgency of this proposition is important as poor women often go unnoticed in the development agenda, as they are invisible in society (Hick, 2004). For instance, the MDG that promotes universal primary education is too general, and does not specifically target poor women. Without being clearly targeted, women will be left out of education because of extreme poverty. Although the Bangladesh government has a good policy with respect to increasing literacy rates, this policy will only reach the poor with good governance and strong support for such national strategies. Good governance and government support is essential for ensuring that poor women are enrolling in vocational training and technology programs and continuing universal education. 


\section{Conclusion}

The researcher believes that an independent income program can create the potential to enhance women's status at home and in the community. The Grameen Bank program has proved this through its micro-lending program. As Kabeer (2003) notes, by increasing women's income, women can have an increased number of choices, networking, greater household decision- making power, greater social status, and greater sense of confidence and independence. Women's empowerment can enable women to oppose authoritative patriarchal power structures through collective action.

Empowering women through education is a big key to change. Otherwise, their human capabilities will not develop, and rich people will eat the fruits of the economy while exploiting and abandoning the poor people. Therefore, there must be opportunities and choice provided for them. This will help to develop their human capabilities and help reduce poverty among women.

Other social, economic and political support at the micro level can assist poor women in the development of their human capabilities. For instance, the rural population needs to operate a variety of self-employment activities. Access to capital via diverse micro-credit and micro-enterprise targeted loan schemes helps to remove the credit constraint and hence accelerates the existence out of poverty. Grameen Bank has proved that micro-credit can create economic and social capital among the rural poor women in Bangladesh (Dowla, 2001). These programs can help to eradicate social discrepancy, gender inequalities, and other social catastrophic activities that affect the bottom $50 \%$ of women in rural Bangladesh.

Women's human rights development discourse differs between developed and developing countries. There are various approaches discussed by different authors within the literature. The literature helps us to understand problems and the position of women in Third World countries. However, I am inclined to agree with Patricia Stamp (1989) and Chandra Mohanty (2003) when they stress the importance of analyzing the use of the literature in development discourse. More specifically, the literature should be used to promote poor women's human rights in Bangladesh, but in such a way that accepts that not all the traditional values of Bangladesh are a constraint to development discourse and practice, and not all Western ideologies can be applied to Bangladesh without considering local contexts. As Beneria (1970) would suggest, development relates to Third World countries, gender and globalization, economic adjustment and feminist economics. These themes should be examined as interrelated dimensions that are relevant to external factors affecting the Bangladesh poverty process and inequality. Freire (1981) notes that through constant dialogue and praxis we can free each other and free ourselves from oppressors. Therefore, people must work together to a find permanent freedom.

Margaret Schuler (1986) offers us a method for understanding and challenging the current legal system. Her concept of the structural component of society (i.e., courts, administrations and law enforcement) should be challenged through advocacy. Building networks and organizing public and private protests and rallies can help to fight against women's exploitation. In addition, activities such as seminars, conferences, workshops, community education, mass media campaigns, and publication of scholarly works, dissemination of information through popular literature, comic books, posters, dance, brochures, theatre, and poetry can initiate programs for women designed to help them claim their inherent rights.

Furthermore, the laws should be reformed in order to allow women freedom to claim their property rights, and freedom of choice. At the same time, the law needs to raise awareness through legal education to reform unequal power for social justice in the society. Greater government intervention and less government corruption is also needed to assist these women.

All over the world, poor women are living such inhuman lives and are exploited by government and the powerful elites. Therefore, it is urgent that we work to establish basic human rights for the poor women. It becomes a question of morality and thus, our duty to help these disadvantaged people survive in society. Empowerment and autonomy of women and improvement of women's social, economic and political status is 
Micro-credit lending programs and the human capabilities approach in Bangladesh

essential for the achievement of both a transparent and accountable government, as well as sustainable women human rights in Bangladesh.

About the Author: Kazi Abdur Rouf, PhD in Adult Education and Community Development at the Ontario Institute for Studies in Education (OISE). He did his Masters in Environmental Studies, Business and Environment (MES) from York University in 2008 and Bachelor of Arts (BA) in Women Studies from York University in 2006. Rouf has worked for Grameen Bank Bangladesh and in other micro-finance institutions in Bangladesh, India, Afghanistan, and Pakistan. Moreover, he worked in Namibia, Lesotho, India, Pakistan, Afghanistan, Philippines, United States and Canada for promoting small and medium enterprises (SME) and self-employment among low income people. Kazi Rouf writes many articles after working for Grameen Bank and other micro-finance institutions around the world for long time. To contact Kazi and for details regarding the references contained in the article please contact him at: rouf56@ hotmail.com.

\section{References:}

Alam, S.M.S. (1995). The state, class formation, and development in Bangladesh. New York: University Press of America, Inc.

Anan, K. (2005). Grameen dialogue 2005. Dhaka: Grameen Trust.

Bangladesh Rural Advancement Committee. (BRAC). (2005). BRAC information. Retrieved July 06, 2005, from http://www.brac.net/

Beneria, L. (2003). Gender, development and globalization: Economics as if people mattered. New York: Routledge.

BIDS. (2005). Fighting human poverty: Bangladesh human development report 2000. An overview of the study prepared by the Bangladesh Institute of Development Studies (BIDS). Retrieved June 17, 2005, from http://www.sdnbd.org/sdi/issues/sustainable_development/bd

BMSP. (1997). State of human rights Bangladesh. Dhaka, Bangladesh: Manobadhikar Samonoy Parishad (BMSP).

Boserup, E. (1970). Women's role in economic development. London: Earthscan Publications.

Canadian International Development Agency (CIDA). (n.d.). Development goals. Ottawa: International Development Research Center. Retrieved June 5, 2005, from http://www.acdi-cida.gc.ca/whatwedo.htm Chouwdhury, A. (2005). Grameen Connections. Newsletter, 7(4). Washington, USA. The Grameen Foundation. CIDA. (2001).Gender profile: Bangladesh. Retrieved June 5, 2005, from http://www.acdi-cida.gc.ca/index.htm

Dollar, D., \& Gatti, R. (2003). In N. Kabeer, Gender mainstreaming in poverty eradication and the millennium development goals (pp. 39-44). Ottawa: International Development Research Center.

Dowla, A. (2001). Grameen dialogue \#60, January 2005. Dhaka: Grameen Trust.

Elson, D. (1998). Talking to the boys: Gender and economic growth models. In C. Jackson \& R. Pearson (Eds.), Feminist vision of development: Gender analysis and policy (pp. 155-170). New York: Routledge.

Elson, D. (2003). Gender justice human rights, and neo-liberal economics politics. In M. Molyneux \& S. Razavi (Eds.), Gender justice development, and rights (pp 78-114). New York: Oxford University Press.

Frank, A. G. (1970). Dependence, imperialism and underdevelopment. In J. Cockcroft, A. G. Frank, \& D. Johnson (Eds.), Dependence and underdevelopment: Latin America's political economy (pp. 3-17). New York: Doubleday \& Company, Inc.

Freire, P. (1981). Pedagogy of the oppressed. New York: Continuum.

Grameen Bank. (2005). Grameen dialogue \#60, January 2005. Dhaka, Bangladesh: Grameen Trust.

Gramsci, A. (1971). The intellectuals. In Q. Hoare \& G. N. Smith (Eds.), Selections from the prison notebook (pp. 4-23). New York: International Publishers.

Hick, S. (2004). Social welfare in Canada-understanding income security. Toronto: Thomson Educational Publishing, Inc.

International Monetary Fund. (n.d.). Retrieved June 17, 2005, from http://www.imf.org/external/pubs/ft/aa/aao1.htm 
Rouf, K. A.

Kabeer, N. (2003) Gender mainstreaming in poverty eradication and the millennium development goals. Ottawa: International Development Research Center.

Karim, A. (1976). Changing society of India, Pakistan and Bangladesh. Dhaka: Nawroze Ketabistan.

Mohanty, C. (2003). Families without borders: Decolonizing theory, practicing solidarity. Durham: Duke University Press

Natsios, A. S. (2005, April 22). Democratic opportunity and the Islamic World. Speech presented by Andrew S. Natsios on behalf of the Centre for the Study of Islam and Democracy. Retrieved June 2, 2005, from http://www.usaid.gov./press/speches/2005/sp050422.html

Novak, J. J. (1993). Bangladesh reflection on the water. Bloomington: Indiana University Press.

Nussabaum, M. (1988) Women's capabilities and social justice. In Molyneux, M. \& Razavi, S. (Eds.), Gender, justice, development and rights (pp 45-74). New York: Oxford University Press.

Paider, P. (2002) Encounters between feminism, democracy and reformism in contemporary Iran. In M.

Molyneux \& S. Razavi (Eds.), Gender Justice Development, and Rights (pp 78-114). New York:

Oxford University Press. http://dx.doi.org/10.1093/0199256454.003.0008

Pally Karma- Sahayak Foundation. (2005). PKSF profile. Retrieved July 07, 2005 from http://www.pksf-bd.org/aprm_summit_new_list_workshops_panelists.htm

Quadir, F. (2003). How "civil" is civil society? Authoritarian state partisan civil society and the struggle for democratic development in Bangladesh. Canadian Journal of Development Studies, 24(3), 425-438.

Said, E. W. (1978). Orientalism. New York: Penguin Books.

Schuler, M. (Ed.). (1986). Empowerment, and the law: strategies of Third World women. Washington, D.C.: OEF International.

Seguino, S. (2003). In N. Kabeer, Gender mainstreaming in poverty eradication and the millennium development goals (pp. 39-44). Ottawa: International Development Research Center.

Shiva, V. (1988). Staying alive: Women, ecology, development. London: Zed Press.

South Asia Foundation. (2001). Bangladesh profile. Retrieved June 8, 2005, from http://www.southasiafoundation.org/saf/bngladesh/banglastats.asp

Stamp, P. (1989). Technology, gender, power in Africa. Ottawa: International Development Research Centre.

United Nations. Department of Public Information. (2000). Gender equality, development and peace for the twenty first century. Women 2000: Beijing. Proceedings of a conference on Women's rights. New York. Retrieved June 17, 2005, from http://www.un.org/womenwatch/daw/followup/session/presskit/fs1.htm

US Agency for International Development (USAID). (n.d.). Retrieved June 17, 2005, from http:///www.usaid.govt/about_usaid/

World Bank. (n.d.). Data and statistics for Bangladesh. Retrieved June 17, 2005, from http://www.worldbank.org/

World Trade Organization (WTO). (n.d.). The future of the WTO. Retrieved June 17, 2005, from http://www.wto.org

Yunus, M. (2002). Grameen dialogue \#52, October 2002. Dhaka, Bangladesh: Grameen Trust. 